\section{Poultry Litter Quantity Influences Collard Growth in Pots and Affects Cabbage Growth and Nutrient Uptake}

\author{
Ningping Lu ${ }^{1}$ \\ Department of Agronomy and Soils, Auburn University, AL 36849-5412
}

\author{
J.H. Edwards ${ }^{2}$ \\ U.S. Department of Agriculture-Agricultural Research Service, National Soil \\ Dynamics Laboratory, P.O. Box 3439, Auburn, AL 36831-3439
}

Additional index words. Brassica oleracea, soil nutrient levels, dry matter yield, residual nutrient levels

\begin{abstract}
A greenhouse pot study was conducted with a Wynnville sandy loam surface soil to determine the influence of application rates of poultry litter (PL) on growth and nutrient uptake of collard (Brassica oleracea, Acephata Group L., cv. Champion), and the residual effects of PL on growth and nutrient uptake of cabbage (Brassica oleracea, Capitata Group L., cv. Rio Verde). PL at $0,13,26,53$, and $106 \mathrm{~g} \mathrm{~kg}^{-1}$ was incorporated into limed (pH 6.5) and nonlimed (pH 5.2) soil. Collard plants were grown for 52 days. The residual effects of PL were evaluated by growing three successive crops of cabbage without further application of PL (total 218 days). Collard plants were severely damaged or killed within 7 days after transplanting when the application rate of PL exceeded $26 \mathrm{~g} \cdot \mathrm{kg}^{-1}$ soil. Maximum dry matter yield of cabbage shifted from 26 to $106 \mathrm{~g} \mathrm{PL/kg}$ soil during three successive crops. After four successive growth periods, $6 \%$ to $37 \%$ of $\mathrm{N}, 3 \%$ to $62 \%$ of $\mathrm{Ca}, 20 \%$ to $120 \%$ of $\mathrm{K}, 5 \%$ to $60 \%$ of $\mathrm{Mg}$, and $3 \%$ to $25 \%$ of $\mathrm{P}$ added through PL was removed by plants. The decrease in water-extractable $K$ accounted for the decrease in the soil salinity. Our results suggest that application rates of $P L \geq 53 \mathrm{~g} \cdot \mathrm{kg}^{-1}$ soil can result in elevated levels of salts and $\mathrm{NH}_{3}$ in soil, which can produce severe salt stress and seedling injury.
\end{abstract}

Land disposal of poultry litter (PL) from broiler chicken (Gallus domesticus) production has been an agricultural practice for years (Payne and Donald, 1991). Land application of PL recycles nutrients and effectively disposes of waste. In Alabama, two types of poultry wastes are produced: broiler litter, which is a mixture of manure and bedding materials, such as wood shavings or peanut hulls and has a moisture content of $\approx 20 \%$, and caged-layer manure, which is free from bedding materials and has a moisture content of $\approx 75 \%$ (Mitchell et al., 1989). More than 25\% of PL dry matter is water soluble and $>50 \%$ of the $\mathrm{N}$ in PL is water soluble (Wilkinson et al., 1971). The total $\mathrm{N}$ in PL in Alabama ranges from $3 \%$ to $4 \%$, but $>70 \%$ of total N in PL is in an organic form (Payne and Donald, 1991).

Received for publication 4 Oct. 1993. Accepted for publication 12 May 1994. Contribution of the Dept. of Agronomy and Soils, U.S. Dept. of Agriculture (USDA)-Agricultural Research Service, National Soil Dynamics Laboratory, and Alabama Agricultural Experiment Station Journal Series no. 3-933590. Mention of a trademark or proprietary product does not constitute a guarantee or warranty of the product by Auburn Univ. or USDA and does not imply its approval to the exclusion of other products that may also be suitable. The cost of publishing this paper was defrayed in part by the payment of page charges. Under postal regulations, this paper therefore must be hereby marked advertisement solely to indicate this fact.

${ }^{1}$ Graduate Research Assistant.

${ }^{2}$ Soil Scientist.
Up to $60 \%$ of organic $N$ in poultry excreta is in the form of uric acid, which will decompose slowly to $\mathrm{NH}_{3}$ and $\mathrm{CO}_{2}$ by aerobic organisms (Eno, 1966). Before the organic fraction of $\mathrm{N}$ can be used by plants, it must be mineralized into inorganic forms (Wilkinson, 1979).

More than 1 million tons of PL is produced annually in a small area of northern Alabama (Hinton, 1991). Thus, PL is seen as a waste disposal problem by producers, and transportation costs restrict the distance that litter can be profitably transported. The end result is that in some areas PL is often spread on dormant and pasture lands at excessive rates in winter, which coincides with a high rainfall and low evapotranspiration season in Alabama (Thomas, 1976). Excess $\mathrm{NO}_{3}-\mathrm{N}$ and other nutrients are thus available to move into surface and groundwater, causing nonpoint source pollution of ground and surface waters (Weil et al., 1979).

Research in states other than Alabama showed that heavy litter application to crop land has caused excessive buildup of soil $P$ and eutrophication of surface waters due to runoff of excessive P (Wilkinson, 1979), ammonia, and nitrite toxicities to germinating seeds (Siegel et al., 1975), and growth-inhibiting levels of soil salinity (Shortall and Liebhardt, 1975). High levels of nitrate-N and $\mathrm{K}$ in tall fescue (Festuca arundinacea Schreb.) tissue from land-applied litter at high rates increased the potential for grass tetany (Wilkinson et al., 1971), a metabolic disorder that can lead to death in grazing animals. However, the exces- sive applications of PL would only be a problem in sandy soils in the year of application with respect to crop growth (Liebhardt, 1976). The highest yields of corn (Zea mays L.), corn forage, and sorghum (Sorghum bicolor L.) occurred in the second year after $224 \mathrm{t}$ of PL/ ha was applied to soil (Liebhardt, 1976). Nitrogen uptake by plants was primarily influenced by PL application rate. Ten percent to $12 \%$ of total $\mathrm{N}$ applied with PL was removed by the crops, and the percent $\mathrm{N}$ removed decreased with increasing application rate (Cooper et al., 1984).

Reported crop responses to PL have been concerned with field crops. To our knowledge, no information about the effect of PL rates on vegetables is available. The objectives of this study were to determine the effects of PL rates on growth and nutrient uptake of collard grown in pots in a greenhouse and to determine the residual effects of PL on cabbage growth and nutrient uptake.

\section{Materials and Methods}

PL that included bedding material (wood shavings) was collected from a poultry house in northern Alabama. Total $\mathrm{N}$ content was $38.5 \mathrm{~g} \cdot \mathrm{kg}^{-1}\left(\mathrm{NH}_{4}-\mathrm{N}, 0.85 ; \mathrm{NO}_{3}-\mathrm{N}, 0.38\right.$; organic $\mathrm{N}, 37.3 \mathrm{~g} \cdot \mathrm{kg}^{-1}$ ) and total $\mathrm{C}, 391 \mathrm{~g} \cdot \mathrm{kg}^{-1}$. The PL had a pH of 8.5 and a moisture content of $14 \%$.

A bulk sample of the Ap horizon (0 to 15 $\mathrm{cm}$ ) of a Wynnville sandy loam soil (fineloamy, siliceous, thermic Glossic Fragiudults) was collected from an idle field at the Sand Mountain Substation, Crossville, Ala. The soil had a pH of 5.2 and consisted of $59.2 \%$ sand, $31.0 \%$ silt, and $8.9 \%$ clay. Ammonium acetateextractable $\mathrm{Ca}$ or $\mathrm{Mg}$ was 1.6 and $0.16 \mathrm{cmol}_{\mathrm{c}} /$ $\mathrm{kg}$, respectively. A cation-exchange capacity (CEC) of $3.6 \mathrm{cmol}_{\mathrm{c}} / \mathrm{kg}$ was obtained by ammonium saturation (Rhoades, 1982a). Soil N content was $0.5 \mathrm{~g} \cdot \mathrm{kg}^{-1}$. Organic matter content of $24.1 \mathrm{~g} \cdot \mathrm{kg}^{-1}$ was determined indirectly by analysis of total organic C using the Walkley-Black procedure of rapid dichromate oxidation (Nelson and Sommer, 1982) and multiplying by a factor of 1.724 to convert organic $\mathrm{C}$ to organic matter content.

A percent field capacity (FC) approximation of $14 \%$ moisture was obtained by a modified method of Cassel and Nielsen (1982) as follows: A 500-g, air-dried soil sample was uniformly packed at a density of $1.2 \mathrm{~g} \cdot \mathrm{cm}^{-1}$ into a glass column; a known quantity of deionized water was added to the soil column; the amount of water added was based on $75 \%$ of estimated FC; the column was covered to prevent evaporation and allowed to drain and equilibrate for $48 \mathrm{~h}$. When the wetting front had stopped, the distance from the top of the original dry soil column to the wetting front was measured. The FC was calculated by

$\mathrm{FC}(\%)=\mathrm{L} \times 100 /[\mathrm{F} \times(\mathrm{S} / \mathrm{D})] \times 100$

where $\mathrm{L}$ is the amount of deionized water added (in milliliters), $F$ is the distance between wetting front and the top of original soil height (in centimeters), $\mathrm{D}$ is the height of the original 
air-dried soil in the column (in centimeters), and $\mathrm{S}$ is the oven-dried soil used (in grams).

Bulk soil was divided into two lots. One was limed according to the lime requirement method of Hue and Evans (1986), and the other was used as a nonlimed control. Dolomitic limestone was added to the soil in a suspension at a rate of $3.67 \mathrm{~g} \cdot \mathrm{kg}^{-1}$ soil (Anderson and Hendrick, 1983) to bring soil $\mathrm{pH}$ up to 6.5. Each lot was carried through three 4-day cycles of wetting and air drying.

$\mathrm{PL}$ at $0,13,26,53$, and $106 \mathrm{~g} \cdot \mathrm{kg}^{-1}$ soil was incorporated into limed or nonlimed soil. No fertilizer amendments were added. Six kilograms of treated soil was placed in $0.28-\mathrm{m}^{3}$ plastic pots without drainage holes; water was added to maintain $25 \%$ soil moisture (dry weight basis), and pots were incubated for 1 week. Two 40-day-old collard seedlings were transplanted into each pot. Temperature was $32 \pm 5 \mathrm{C}$ during the growing period. Soil moisture was adjusted daily (dry weight basis). Plants were harvested 52 days after transplanting, and the leaves, stems, and roots were separated. Soil was collected from four individual pots from each PL treatment for chemical analyses.

Soil from each initial PL treatment and replication was combined and thoroughly mixed, no further PL was added, and $6 \mathrm{~kg}$ soil was returned to each pot. Two 30-day-old cabbage seedlings were transplanted into each pot. One cabbage plant was harvested at 34 days and the other at 75 days after transplanting. Leaves and roots were harvested separately. Soil also was collected from individual pots for chemical analyses. Before the third cabbage crop was planted, commercial fertilizer $\left(150 \mathrm{~N}-60 \mathrm{P}-120 \mathrm{~K} \mathrm{mg} \cdot \mathrm{kg}^{-1}\right.$ soil $)$ was added to soil of the 0 PL treatment to adjust the fertilizer to original levels. No fertilizer was added to the soils amended with PL. After mixing soil from each PL treatment and replication and returning $6 \mathrm{~kg}$ to each pot, cabbage seeds were planted; seedlings were thinned to two plants 18 days after emergence. Cabbage plants were harvested 56 days after thinning. Leaves and roots were harvested separately. Soil was collected from individual pots for chemical analyses.

All plant tissue was oven-dried at $60 \mathrm{C}$, weighed, and ground to pass through a 0.425 $\mathrm{mm}$ sieve. Leaf $\mathrm{N}$ was determined by a Kjeldahl method (Bremner and Mulvaney, 1982). Mineral elements in leaves, stems, and roots were obtained by dry-ashing (Hue and Evans, 1986). Concentrations of $\mathrm{Ca}, \mathrm{K}, \mathrm{Mg}$, and $\mathrm{P}$ were determined by inductively coupled argon plasma (ICAP) spectrophotometry.

Soil samples collected from each treatment at each harvest were air-dried and ground to pass through a $0.84-\mathrm{mm}$ sieve. Soil $\mathrm{pH}$ was measured on 1 soil : 1 water ratio of slurries. Soil samples were extracted with water to determine soluble $\mathrm{Ca}, \mathrm{K}, \mathrm{Mg}, \mathrm{P}$, and specific conductance (SC) (Petruzzelli et al., 1989; Rhoades, 1982b). The extraction procedure was modified and used as follows: A ratio of 1 soil : 2 water suspension was shaken on a reciprocal shaker for $12 \mathrm{~h}$. Samples were centrifuged for $20 \mathrm{~min}$ at $850 \times \mathrm{g}$ to remove soil and organic material. The supernatant solution was centrifuged for $10 \mathrm{~min}$ at $16000 \times \mathrm{g}$, and finally filtered through a $0.2-\mu \mathrm{m}$ nylon membrane filter under vacuum to remove suspended colloidal materials. The $\mathrm{Ca}, \mathrm{K}, \mathrm{Mg}$, and $\mathrm{P}$ concentrations were determined by ICAP spectrophotometry. The electrical conductivity of the solution was measured with a conductivity bridge. The $\mathrm{SC}$ was calculated by the method of Hue and Evans (1986), as follows:

$\mathrm{SC}=\left(1.4118 \times \mathrm{C}_{\mathrm{ext}}\right) / \mathrm{C}_{\text {std }}$

where 1.4118 is the SC of the standard $0.01 \mathrm{M}$ $\mathrm{KCl} ; \mathrm{C}_{\text {std }}$ is the measured conductivity of the standard solution; $\mathrm{C}_{\mathrm{ext}}$ is the measured conductivity of the extracted solution.

Total soil N was determined by a Kjeldahl method (Bremner and Mulvaney, 1982). Extractable $\mathrm{NH}_{4}-\mathrm{N}$ and $\left(\mathrm{NO}_{3}+\mathrm{NO}_{2}\right)-\mathrm{N}$ concentrations were determined by a modified method of Keeney and Nelson (1982). Samples at a 1:2 ratio of soil to $2 \mathrm{M} \mathrm{KCl}$ were shaken for $1 \mathrm{~h}$. Suspensions were centrifuged for $20 \mathrm{~min}$ at $850 \times g$ and then filtered. Ammonium-N was obtained by steam-distilling the extract in the presence of a base solution. The distillates were collected into a $2 \% \mathrm{H}_{3} \mathrm{BO}_{3}$-indicator solution. After removing $\mathrm{NH}_{4}-\mathrm{N},\left(\mathrm{NO}_{3}+\mathrm{NO}_{2}\right)-\mathrm{N}$ was obtained by distilling the extract in the presence of Devarda's alloy. The concentrations of $\mathrm{NH}_{4}-\mathrm{N}$ and $\left(\mathrm{NO}_{3}+\mathrm{NO}_{2}\right)-\mathrm{N}$ in the distillates were determined by titrating with $0.05 \mathrm{M} \mathrm{HCl}$.

An estimate of the percentage of $\mathrm{N}$ and other nutrients absorbed by collard and cabbage plants at PL rates of 13 to $106 \mathrm{~g} \cdot \mathrm{kg}^{-1}$ soil was calculated using the following equation:

$\% \mathrm{E}_{\mathrm{est}}=\left[\left(\mathrm{TN}_{\mathrm{PL}}\right)_{1 \ldots \mathrm{i}}-\mathrm{TN}_{\mathrm{ck}}\right] /\left(\mathrm{TNA}_{\mathrm{PL}}\right)_{1 \ldots i}$ $\times 100$

where $\% \mathrm{E}_{\text {est }}$ is the percentage of each nutrient absorbed; $\mathrm{TN}_{\mathrm{PL}}$ is the sum total of nutrients (grams per plant) obtained from PL for all growth periods; subscripts 1 ...i refer to each $\mathrm{PL}$ rate; $\mathrm{TN}_{\mathrm{ck}}$ is the sum total of nutrients absorbed in $0 \mathrm{PL}$; $\mathrm{TNA}_{\mathrm{PL}}$ refers to the total nutrients added in the PL.

The design was a split plot with four replications. Main plots were lime levels and subplots were PL at $0,13,26,53$, and $106 \mathrm{~g} \cdot \mathrm{kg}^{-1}$ soil and four growth periods. All treatment combinations were completely randomized.

All statistical analyses were performed using the Statistical Analysis System (SAS), version 6.03 (SAS Institute, 1988). The general linear model (GLM) procedure using type III sums of squares was used to identify the significance of PL rates for one crop of collard and three crops of cabbage. The slope $(\beta)$ of the regression line for each crop was tested by using the rate $\times$ growth period interaction when all growth periods were combined into one data set. When this interaction was not statistically significant, the regression lines presented are for data averaged over PL rates for each growth period. Orthogonal polynomial contrasts were used to determine whether the response to treatments was linear, quadratic, or both. Unless otherwise noted, all statistical tests were reported at $P \leq 0.05$.

\section{Results and Discussion}

Collard growth and dry matter yield. Collard seedlings were severely stunted or killed in limed and nonlimed soils. With 53 or $106 \mathrm{~g}$ $\mathrm{PL} / \mathrm{kg}$ soil, all collard seedlings died within 7 days after transplanting (Table 1). However, the percentage of seedlings that survived decreased linearly as PL rates increased from 0 to


soil, $\approx 2$ times as many seedlings survived in nonlimed as in limed soil. When the $\mathrm{pH}$ was 6.5 or above due to liming, the number of surviving seedlings decreased by $50 \%$ when compared to those in nonlimed soil. We attribute collard seedling death in this experiment to the initial high concentration of soil $\mathrm{NH}_{3}$ and elevated salt content that occurred after PL application. In an aerobic incubation study (Lu, 1993), 70\% of organic N present in PL was mineralized during 28 days of incubation, and 650 to $1000 \mathrm{mg} \cdot \mathrm{kg}^{-1}$ of $\mathrm{NH}_{4}-\mathrm{N}$ accumulated in the soil when PL application rate was $\geq 53 \mathrm{~g} \cdot \mathrm{kg}^{-1}$ soil. The cumulative $\mathrm{NH}_{3}$ evolution reached $120 \mathrm{mg} \cdot \mathrm{kg}^{-1}$ at $106 \mathrm{~g} \mathrm{PL} / \mathrm{kg}$ soil at the end of the 28 days of incubation. Emission of $\mathrm{NH}_{3}$ gas was quadratically related to time after PL application.

The dry weights of collard seedlings are reported as grams per plant of surviving transplants. In limed soil, when $26 \mathrm{~g}$ PL/kg soil was applied, only one plant out of eight in the four replications survived (Table 1 ). Since only one plant survived in this treatment, no regression analysis was conducted on dry weights. However, a comparison between the dry weight of leaves at $13 \mathrm{~g} \mathrm{PL} / \mathrm{kg}$ soil and $0 \mathrm{PL}$ was made $(P \leq 0.05)$. The dry weight of leaves at $13 \mathrm{~g} \mathrm{PL/}$ $\mathrm{kg}$ soil increased by $59 \%$ when compared to 0 PL. In nonlimed soil, the dry weight of leaves increased linearly with increasing PL application rate $(P \leq 0.1)$. The dry weight of stems or roots was not significantly influenced by PL application rate.

SC was not affected by liming. The soil SC was averaged over lime levels and increased linearly with increasing PL application rates for all growth periods (Fig. 1). Because there was no statistically significant growth period $\times$ PL rate interaction between the initial values and the collard growth period, or between cabbage 1 and cabbage 2 growth periods, the regression lines presented are data averaged over PL rates. At $26 \mathrm{~g} \mathrm{PL} / \mathrm{kg}$ soil, the soil SC averaged $0.2 \mathrm{~S} \cdot \mathrm{m}^{-1}$, which resulted in decreased plant survival and reduction in total dry weight of collard. Adding PL at 53 and $106 \mathrm{~g} \cdot \mathrm{kg}^{-1}$ soil increased soil SC up to 0.3 and $0.52 \mathrm{~S} \cdot \mathrm{m}^{-1}$, respectively. High soil SC may have been a contributing factor in the death of collard seedlings. Hue and Evans (1986) reported that $\mathrm{SC}$ of 0.081 to $0.16 \mathrm{~S} \cdot \mathrm{m}^{-1}$ caused a reduction of $50 \%$ in yield of fruits, vegetable crops, some sensitive forage, and field crops. Only a few highly salt-tolerant grasses, herbaceous plants, shrubs, and trees grow when SC exceeds 0.3 $\mathrm{S} \cdot \mathrm{m}^{-1}$.

PL and liming both significantly influenced soil $\mathrm{NH}_{4}-\mathrm{N}$. Because there was no statistically significant growth period $\times$ PL rate interaction for soil $\mathrm{NH}_{4}-\mathrm{N}$ between cabbage 2 
Table 1. Dry weights of collard ${ }^{\mathrm{z}}$ seedlings grown in limed and nonlimed soil amended with 0 to $106 \mathrm{~g}$ poultry litter (PL)/kg soil.

\begin{tabular}{|c|c|c|c|c|c|}
\hline \multirow{2}{*}{$\begin{array}{l}\text { PL } \\
\left(\mathrm{g} \cdot \mathrm{kg}^{-1}\right)\end{array}$} & \multirow{2}{*}{$\begin{array}{c}\text { Plant } \\
\text { survival } \\
(\%)\end{array}$} & \multicolumn{4}{|c|}{ Dry matter wt (g/plant) } \\
\hline & & Leaves & Stems & Roots & Total \\
\hline \multicolumn{6}{|l|}{ Limed } \\
\hline 0 & 62 & 6.4 & 3.0 & 2.0 & 12.4 \\
\hline 13 & 37 & 10.2 & 3.4 & 3.4 & 17.0 \\
\hline 26 & $23^{y}$ & 15.0 & 3.8 & 1.7 & 20.5 \\
\hline 53 & $---x$ & --- & --- & --- & --- \\
\hline 106 & --- & --- & --- & --- & --- \\
\hline$r^{2}$ & 0.97 & & & & \\
\hline \multicolumn{6}{|c|}{ Nonlimed } \\
\hline 0 & 87 & 5.1 & 1.8 & 1.4 & 8.3 \\
\hline 13 & 75 & 8.9 & 4.3 & 3.4 & 16.6 \\
\hline 26 & 54 & 8.3 & 3.3 & 2.1 & 13.7 \\
\hline 53 & $--^{x}$ & --- & --- & --- & --- \\
\hline 106 & --- & --- & --- & --- & --- \\
\hline$r^{2}$ & 0.98 & $0.67^{*}$ & NS & NS & NS \\
\hline
\end{tabular}

${ }^{2}$ Dry weights are reported per plant for surviving seedlings transplanted.

${ }^{y}$ Only one plant out of the four replications survived.

${ }^{x}$ Collard seedlings died.

Ns, ${ }^{*}$ Nonsignificant or significant only at $P \leq 0.1$.



Fig. 1. Effects of poultry litter rates on specific conductance after the growth of one crop of collard and three crops of cabbage.

and cabbage 3 growth periods in limed soil and all three cabbage growth periods in nonlimed soil, the regression lines are data averaged over PL rates (Fig. 2). When PL was incorporated at 53 or $106 \mathrm{~g} \cdot \mathrm{kg}^{-1}$ soil, the soil $\mathrm{NH}_{4}-\mathrm{N}$ ranged from 158 to $178 \mathrm{mg} \cdot \mathrm{kg}^{-1}$ in limed soil and from 115 to $164 \mathrm{mg} \cdot \mathrm{kg}^{-1}$ in nonlimed soil when collard plants were transplanted (Fig. 2). At these two PL rates, initial soil $\mathrm{pH}$ was $\geq 7.5$ (Table 2), which favors the conversion of $\mathrm{NH}_{4}-\mathrm{N}$ to $\mathrm{NH}_{3}$. High concentration of soil $\mathrm{NH}_{3}$, combined with high soil salinity, may have resulted in severe damage to or death of seedlings. At $26 \mathrm{~g} \mathrm{PL} / \mathrm{kg}$ soil, the soil $\mathrm{NH}_{4}-\mathrm{N}$ was $80 \mathrm{mg} \cdot \mathrm{kg}^{-1}$ in limed soil with $\mathrm{pH} 7.5$, and $57 \mathrm{mg} \cdot \mathrm{kg}^{-1}$ in nonlimed soil with $\mathrm{pH} 7.1$. Research reported by Shortall and Liebhardt (1975) and Hileman (1971) showed that high levels of soil salinity, along with high concentrations of soil $\mathrm{NH}_{3}$, were the most important causes of toxicity to corn plants and yield reduction in corn forage.

Effects of residual PL on cabbage growth. After collard plants were grown for 52 days and harvested, the first cabbage crop was grown for 34 days after transplanting. Lime did not influence dry matter production of any of the three successive cabbage crops; the dry weights reported are averages for limed and nonlimed treatments (Fig. 3). In the first cabbage crop, residual PL in the soil from the 13 , 26 , and $53 \mathrm{~g} \cdot \mathrm{kg}^{-1}$ treatments did not stunt cabbage growth. High soil SC $\left(0.48 \mathrm{~S} \cdot \mathrm{m}^{-1}\right)$ and soil $\mathrm{NH}_{4}-\mathrm{N}$ under alkaline conditions (soil $\mathrm{pH}$ 7.4 to 7.6) may have caused toxic effects to the first cabbage crop at $106 \mathrm{~g}$ PL/kg soil.
The second cabbage crop was grown for 75 days after transplanting. Dry weights were highest at 26 and $53 \mathrm{~g} \mathrm{PL} / \mathrm{kg}$ soil. However, cabbage dry weight from $106 \mathrm{~g}$ PL/kg soil showed no statistically significant difference when compared to 0 PL (Fig. 3). At 106 g PL/ $\mathrm{kg}$, the soil SC was $0.24 \mathrm{~S} \cdot \mathrm{m}^{-1}$ (Fig. 1), which may have inhibited plant growth. The maximum soil salinity without yield loss of the edible part of cabbage is $0.18 \mathrm{~S} \cdot \mathrm{m}^{-1}$ (Lorenz and Maynard, 1988).

The third cabbage crop was grown for 56 days after thinning. The reduction in dry weights at 13,26 , and $53 \mathrm{~g} \mathrm{PL/kg} \mathrm{soil} \mathrm{may}$ have been the result of insufficient $\mathrm{N}$ in the residual PL for maximum production of this crop.

Plant $N$ uptake. The leaf $\mathrm{N}$ of collard increased quadratically with increasing PL application rate. Of the three successive cabbage crops, as PL application rate increased, leaf $\mathrm{N}$ concentration of cabbage 1 and cabbage 2 crops increased quadratically, but leaf $\mathrm{N}$ of cabbage 3 crop decreased quadratically (Fig. 4). In the third cabbage crop, at 13 and $26 \mathrm{~g} \mathrm{PL} /$ $\mathrm{kg}$ soil, the leaf $\mathrm{N}$ of $9 \mathrm{~g} \cdot \mathrm{kg}^{-1}$ is considered below sufficient levels ( 22 to $31 \mathrm{~g} \mathrm{~N} / \mathrm{kg}$ ) for normal cabbage plant growth (Lorenz and Maynard, 1988) and contributed to reduction in dry matter yield of cabbage at these two PL rates.

The estimated total $\mathrm{N}$ from PL absorbed by one crop of collard and three crops of cabbage was calculated using Eq. [3] and was based on grams per surviving plant. The total $\mathrm{N}$ added to soil through PL was linearly related to application rate. However, the percentage of $\mathrm{N}$ absorbed by the plants decreased linearly with increasing PL application rate. As PL rate increased from 13 to $106 \mathrm{~g} \cdot \mathrm{kg}^{-1}$ soil, the percent $\mathrm{N}$ removed by plants decreased linearly from $37 \%$ to $6.3 \%$ after one crop of collard and three crops of cabbage.

Plant uptake of Ca, K, $\mathrm{Mg}$, and P. Lime did not affect $\mathrm{Ca}, \mathrm{K}$, and $\mathrm{P}$ concentrations in the leaves and stems of collards; thus, the nutrient concentrations reported are averaged across limed and nonlimed treatments. At 13 and 26 $\mathrm{g} \mathrm{PL} / \mathrm{kg}$ soil, $\mathrm{K}$ ranged from 53 to $66 \mathrm{~g} \cdot \mathrm{kg}^{-1}$ in the edible portion of collard plants (data not shown), which was much higher than the $\mathrm{K}$ levels of 20 to $40 \mathrm{~g} \cdot \mathrm{kg}^{-1}$ in the midrib of wrapper leaves of cabbage under normal fertilizer levels reported by Lorenz and Maynard (1988). The concentration of P in collard plants increased linearly from 8 to $14 \mathrm{~g} \cdot \mathrm{kg}^{-1}$ as PL rate increased from 0 to $26 \mathrm{~g} \cdot \mathrm{kg}^{-1}\left(r^{2}=0.97\right)$, while the concentrations of $\mathrm{Ca}$ and $\mathrm{Mg}$ in plants decreased from 42 to $36 \mathrm{~g} \cdot \mathrm{kg}^{-1}$ as PL rate increased (data not shown). The $\mathrm{Ca}$ concentration was much higher in leaves (average $30 \mathrm{~g} \cdot \mathrm{kg}^{-1}$ over PL treatments) than in stems (average $7.8 \mathrm{~g} \cdot \mathrm{kg}^{-1}$ ), indicating that $\mathrm{Ca}$ achieved distribution via the xylem to transpirational sinks.

The percentage of $\mathrm{Ca}, \mathrm{Mg}, \mathrm{K}$, or $\mathrm{P}$ from $\mathrm{PL}$ absorbed by one crop of collard and three crops of cabbage was calculated using Eq. [3]. Since there was no statistically significant difference in the percentage of $\mathrm{Ca}$ and $\mathrm{Mg}$ absorbed by plants, the regression line shows 


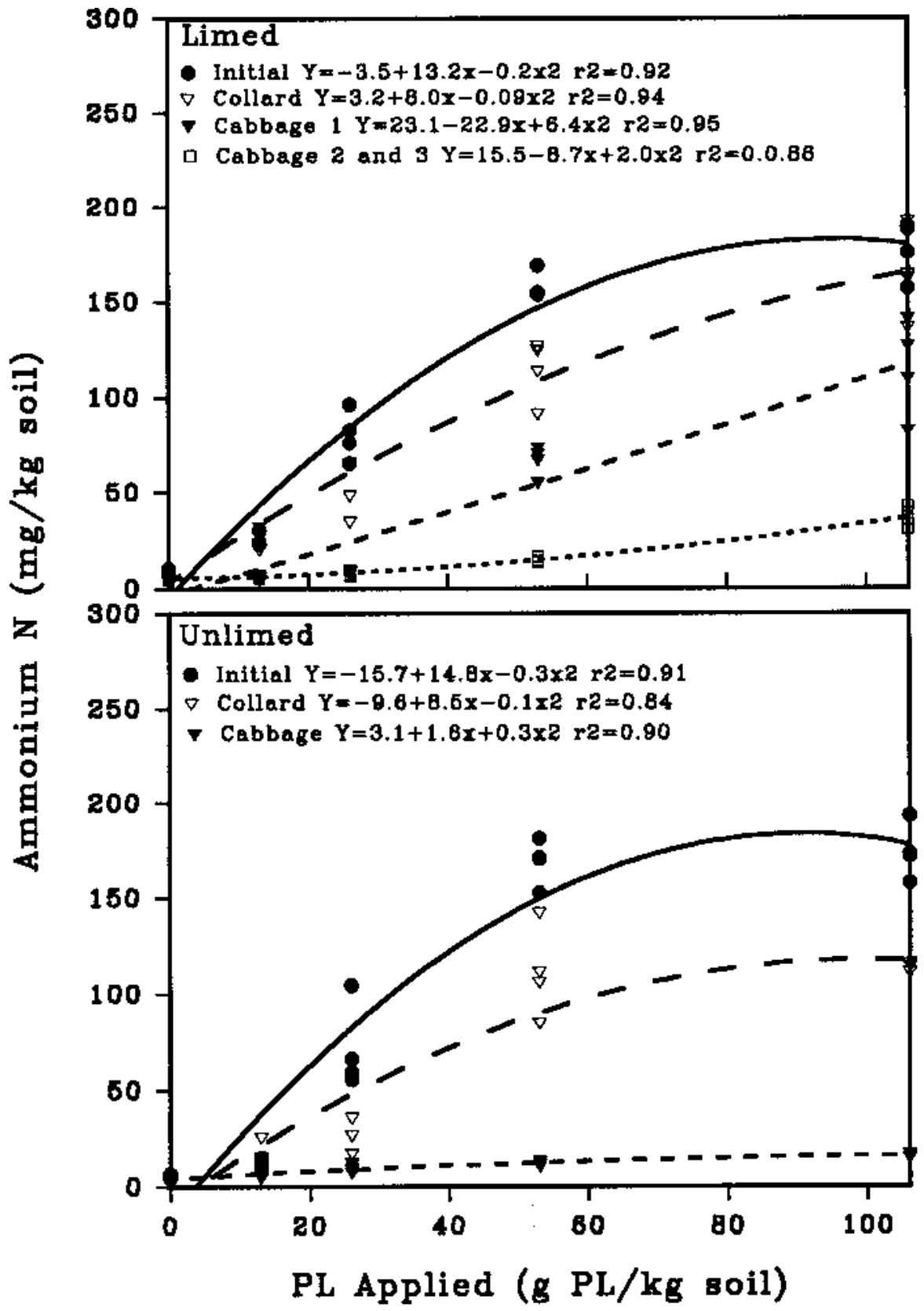

Fig. 2. Changes in $\mathrm{NH}_{4}-\mathrm{N}$ of a Wynnville sandy loam surface soil as affected by poultry litter application rate during four successive growth periods.

Table 2. Soil $\mathrm{pH}$ in limed and nonlimed soil initially amended with 0 to $106 \mathrm{~g}$ poultry litter (PL)/kg soil during the growth of one crop of collard and three crops of cabbage.

\begin{tabular}{lccccc}
\hline \hline $\begin{array}{l}\mathrm{PL} \\
\left(\mathrm{g} \cdot \mathrm{kg}^{-1}\right)\end{array}$ & \multicolumn{5}{c}{ Growth period } \\
\cline { 2 - 6 } Limed & Initial & Collard & Cabbage 1 & Cabbage 2 & Cabbage 3 \\
\hline 0 & \multicolumn{5}{c}{ Soil $p H$ (1 soil : 1 water) } \\
13 & 6.5 & 6.3 & 6.3 & 6.2 & \\
26 & 7.3 & 6.7 & 7.0 & 7.3 & 7.1 \\
53 & 7.5 & 6.5 & 6.7 & 7.1 & 7.1 \\
106 & 7.7 & 7.1 & 7.0 & 7.0 & 7.0 \\
$r^{2}$ & 8.0 & 7.4 & 7.6 & 6.9 & 6.9 \\
Nonlimed & 0.85 & 0.94 & 0.9 & NS & NS \\
0 & 5.2 & 5.6 & 5.8 & 5.5 & 5.3 \\
13 & 6.8 & 5.7 & 6.1 & 5.9 & 5.6 \\
26 & 7.1 & 6.0 & 6.8 & 6.2 & 6.1 \\
53 & 7.6 & 6.9 & 6.3 & 6.9 & 6.7 \\
106 & 8.1 & 7.6 & 7.4 & 7.0 & 7.2 \\
$r^{2}$ & 0.8 & 0.98 & 0.86 & 0.91 & 0.96 \\
\hline
\end{tabular}

NsNonsignificant. the mean of $\mathrm{Ca}$ and $\mathrm{Mg}$. The percentage of $\mathrm{Ca}$, $\mathrm{Mg}, \mathrm{K}$, and $\mathrm{P}$ absorbed by plants decreased linearly with increasing PL application rate (Fig. 5). After four successive crops, $\approx 3 \%$ to $62 \%$ of $\mathrm{Ca}, 4.5 \%$ to $60 \%$ of $\mathrm{Mg}$, and $3 \%$ to $25 \%$ of $\mathrm{P}$ added through PL were removed by plants. The crops absorbed not only $\mathrm{K}$ added through PL, but also some of the soil K when 13 or $26 \mathrm{~g} \cdot \mathrm{kg}^{-1}$ soil was incorporated into soil; thus at 13 and $26 \mathrm{~g} \mathrm{PL} / \mathrm{kg}$ soil, the plants absorbed $110 \%$ to $125 \%$ of soil $\mathrm{K}$ after four successive crops (Fig. 5).

The estimates of plant recovery of nutrients from PL were calculated by Eq. [3]. This equation approximately described the relationship between the nutrients absorbed and PL application rates. However, Eq. [3] had two assumptions. In an incubation study (Lu et al., 1991), soil extraction of nutrients was linearly related to PL application rate. Thus, we assumed that the initial concentration of soil nutrients was not altered by PL application and plants in PL-treated pots absorbed the same proportion of nutrients as plants at $0 \mathrm{PL}$, and additional nutrients in plant tissue were a result of nutrients absorbed from PL. Plants grown in PL-amended soil may actually absorb more nutrients from PL than from soil because the nutrients in PL may be more available for plants than nutrients in soil. Second, we assumed each successive growth period did not affect the ratio of nutrients absorbed by plants at 0 PL. In some cases, these assumptions can lead to over- or underestimation of nutrient recovery from $\mathrm{PL}$.

Water-extractable $P, K, C a$, and $M g$. The increased $\mathrm{K}$ removed by plants resulted in decreases of $93 \%$ to $71 \%$ in water-extractable $\mathrm{K}$ (data not shown), resulting in reduction in the soil SC. The SC was linearly related to the concentration of water-extractable $\mathrm{K}(\mathrm{y}=$ $-97.3+338.7 x)\left(r^{2}=0.99\right)$. We attributed the decrease in water-extractable $\mathrm{K}$ to removal of $\mathrm{K}$ by the plants since plants were grown in pots without drainage holes.

Water extraction of soil is used to give an approximation of soil solution values (Adams, 1974). Soil solution is the medium in which most soil chemical reactions occur, and from which roots obtain nutrients.

After four successive crops, as PL rate increased from 13 to $106 \mathrm{~g} \cdot \mathrm{kg}^{-1}$, soil levels of water-extractable $\mathrm{P}$ decreased from $52 \%$ to $19 \%$, water-extractable $\mathrm{Ca}$ decreased from $92 \%$ to $55 \%$, and water-extractable $\mathrm{Mg}$ decreased from $92 \%$ to $45 \%$. Decreases in waterextractable $\mathrm{P}, \mathrm{Ca}$, and $\mathrm{Mg}$ may have resulted from removal by plants and also by precipitation of $\mathrm{P}, \mathrm{Ca}$, and $\mathrm{Mg}$ under alkaline soil conditions $(\mathrm{pH}>7.2)$. Phosphorus in PL is mainly in the organic form and becomes available to the plant slowly (Beegle, 1988). In a 140-day incubation study, water-extractable $P$ remained at $<8 \mathrm{mg} \cdot \mathrm{kg}^{-1}$ during the first 6 weeks of incubation, but the concentration of water-extractable $\mathrm{P}$ had increased to $>50$ $\mathrm{mg} \cdot \mathrm{kg}^{-1}$ after 6 weeks of incubation. During this period, the extractable $\mathrm{Al}$ decreased from 300 to $2 \mathrm{mg} \cdot \mathrm{kg}^{-1}$ (Lu et al., 1991). However, under alkaline conditions, the decrease in water-extractable $\mathrm{P}, \mathrm{Ca}$, and $\mathrm{Mg}$ may be attrib- 


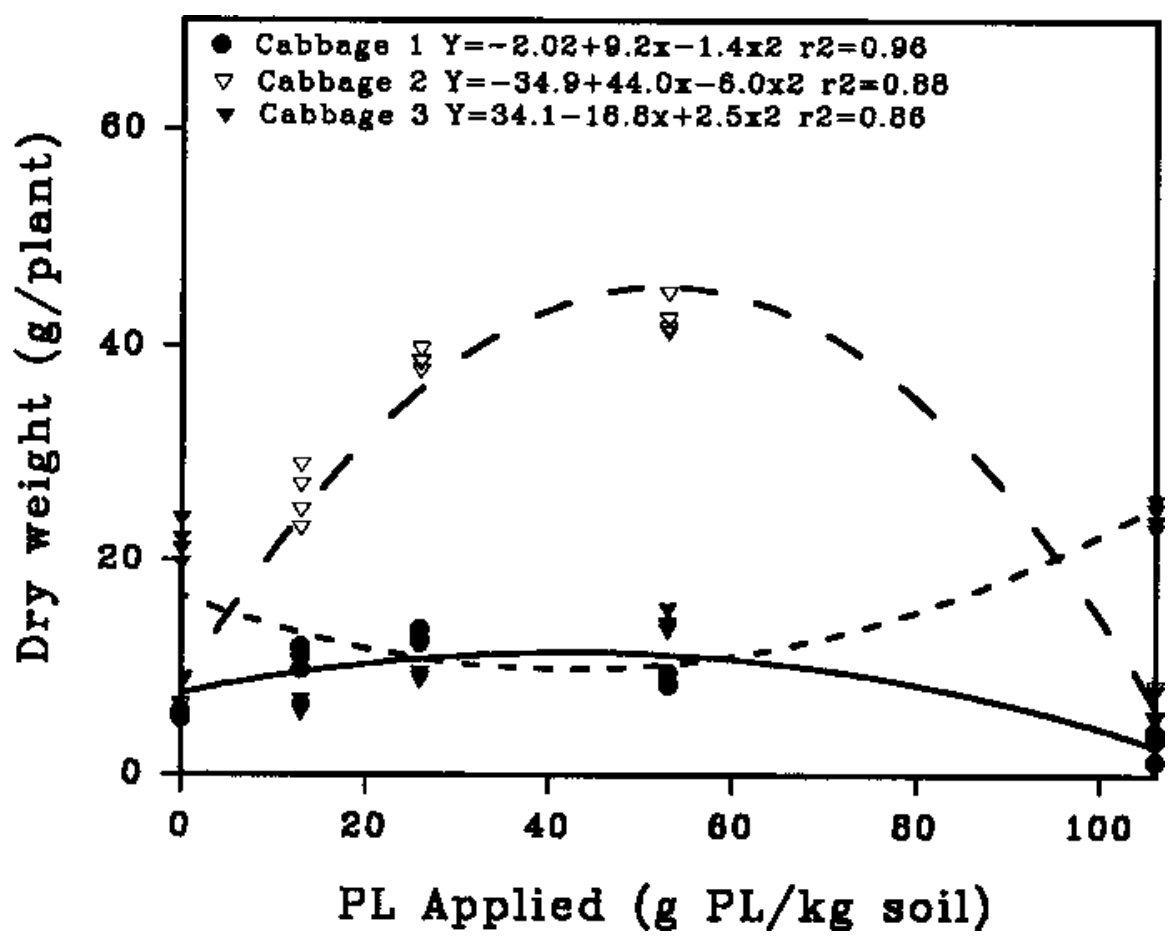

Fig. 3. Dry weight of three crops of cabbage grown in the same soil after collards were harvested.

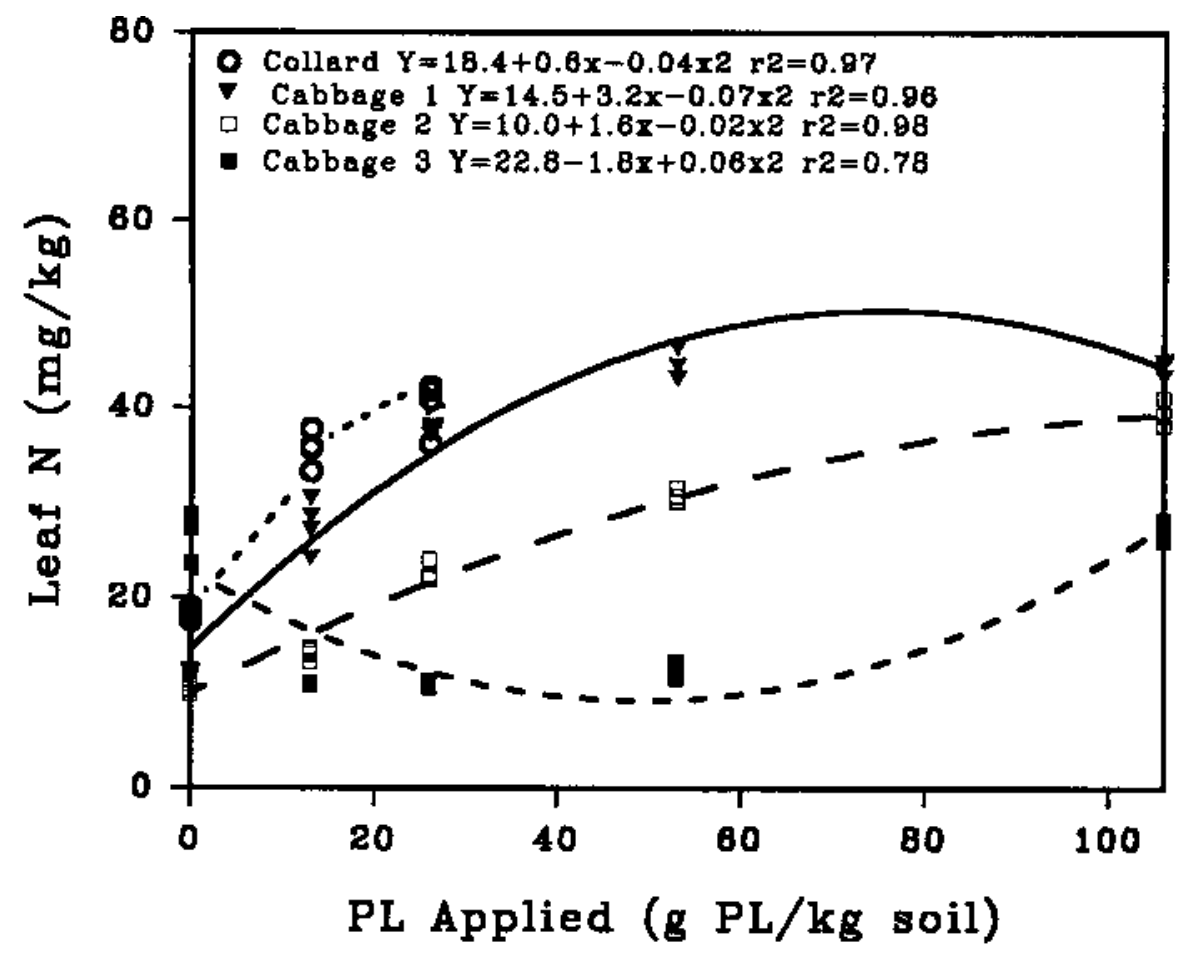

Fig. 4. Mean N concentration in leaves of one crop of collard and three crops of cabbage in soil initially amended with poultry litter at 0 to $106 \mathrm{~g} \cdot \mathrm{kg}^{-1}$ soil.

uted to the precipitation of $\mathrm{Ca}-\mathrm{P}, \mathrm{Mg}-\mathrm{P}, \mathrm{Ca}-$ Mg-P, or Al-P complexes (Lu, 1993; Lu et al., 1991).

\section{Conclusions}

Our results suggest that PL can be used as a plant nutrient source for vegetable production. The optimum PL rate for one crop appears to be $13 \mathrm{~g} \cdot \mathrm{kg}^{-1}$ soil. When this PL rate was exceeded, we encountered elevated salt levels and $\mathrm{NH}_{3}$ concentrations $(\mathrm{Lu}, 1993)$ in soil that resulted in stunted or dead plants. The $\mathrm{N}$ from PL was used more efficiently by succeeding crops when the soil $\mathrm{pH}$ was $>6.5$; the volatilization of $\mathrm{NH}_{3}$ was reduced due to the conversion of $\mathrm{NH}_{3}$ to the $\mathrm{NH}_{4}-\mathrm{N}$ that could be absorbed by succeeding crops. Also, $\mathrm{N}$ use efficiency generally declined as the PL rate was increased beyond the requirements for maximum dry matter production. For more efficient nutrient use, it appears that the nutri- ents needed for each crop should be added before planting that crop, rather than trying to supply nutrients for more than one crop by applying elevated PL rates.

With higher PL application rates $\left(\geq 53{\mathrm{~g} \cdot \mathrm{kg}^{-1}}^{-1}\right.$, soil salinity and $\mathrm{NH}_{3}$ in soil are probably the major causes of collard seedling death. Residual PL in soil amended with 13 to $53 \mathrm{~g} \cdot \mathrm{kg}^{-1}$ soil did not cause toxicity to the first cabbage crop. The soil SC was reduced largely by plant absorption in this experiment. The decrease in water-extractable K accounted for the decrease in the total soil salinity. Application of $13 \mathrm{~g}$ $\mathrm{PL} / \mathrm{kg}$ soil to the sandy loam soil used in this study is more efficient in terms of nutrients absorbed by crops of collard and cabbage than when PL application rates are $\geq 53 \mathrm{~g} \cdot \mathrm{kg}^{-1}$ soil.

\section{Literature Cited}

Adams, F. 1974. Soil solution, p. 441-481. In: E.W. Carson (ed.). The plant root and its environment. The University Press of Virginia, Charlottesville, Va.

Anderson, D.L. and J.G. Hendrick. 1983. Subsoil lime injector. Soil Sci. Soc. Amer. J. 47:337339.

Beegle, D.B. 1988. Fertilizer value of poultry manure and commercial fertilizers, p. 120-124. In: Proceedings of the national poultry waste management symposium. Ohio State Univ., Columbus.

Bremner, J.M. and C.S. Mulvaney. 1982. Nitrogen-Total, p. 599-618. In: A.L. Page et al (eds.). Methods of soil analysis. Part 2-Chemical and microbiological properties. 2nd ed Agron. Soc. Amer., Soil Sci. Soc. Amer., Madison, Wis.

Cassel, D.K and D.R. Nielsen. 1982. Field capacity and available water capacity, p. 901-913. In: A. Klute (ed.). Methods of soil analysis. Part 1Physical and mineralogical methods. 2nd ed. Agron. Soc. Amer., Soil Sci. Soc. Amer., Madison, Wis.

Cooper, J.R., R.B. Reneav, Jr., W. Kroontje, and G.D. Jones. 1984. Distribution of nitrogenous compounds in a Rhodic Paleudult following heavy manure application. J. Environ. Qual. 13:189-193.

Eno, C.F. 1966. Chicken manure-Its production, value, preservation and disposition. Univ. of Florida Agr. Expt. Sta. Circ. S-140.

Hileman, L.H. 1971. Effect of rate of poultry manure application on selected soil chemical properties, p. 247-248. In: Proc. 2nd Intl. Symp. Livestock Wastes. Ohio State Univ., Amer. Soc. Agr. Eng., St. Joseph, Mich.

Hinton, S.A. 1991. Poultry review. In: Alabama agricultural statistics. Bul. 34:41. Alabama Agr. Stat. Serv., Alabama Dept. Agr. and Ind., Montgomery.

Hue, N.V. and C.E. Evans. 1986. Procedures used for soil and plant analysis by the Auburn University Soil Testing Laboratory. p. 22-23.

Keeney, D.R. and D.W. Nelson. 1982. NitrogenInorganic forms, p. 651-654. In: A.L. Page et al. (eds.). Methods of soil analysis. Part 2-Chemical and microbiological properties. 2nd ed. Agron. Soc. Amer., Soil Sci. Soc. Amer., Madison, Wis.

Liebhardt, W.C. 1976. Soil characteristics and corn yield as affected by previous applications of poultry manure. J. Environ. Qual. 5:459-462.

Lorenz, O.A. and D.N. Maynard. 1988. Knott's handbook for vegetable growers. 3rd ed. Wiley, New York.

Lu, N. 1993. Nitrogen mineralization in a Fragiudult 


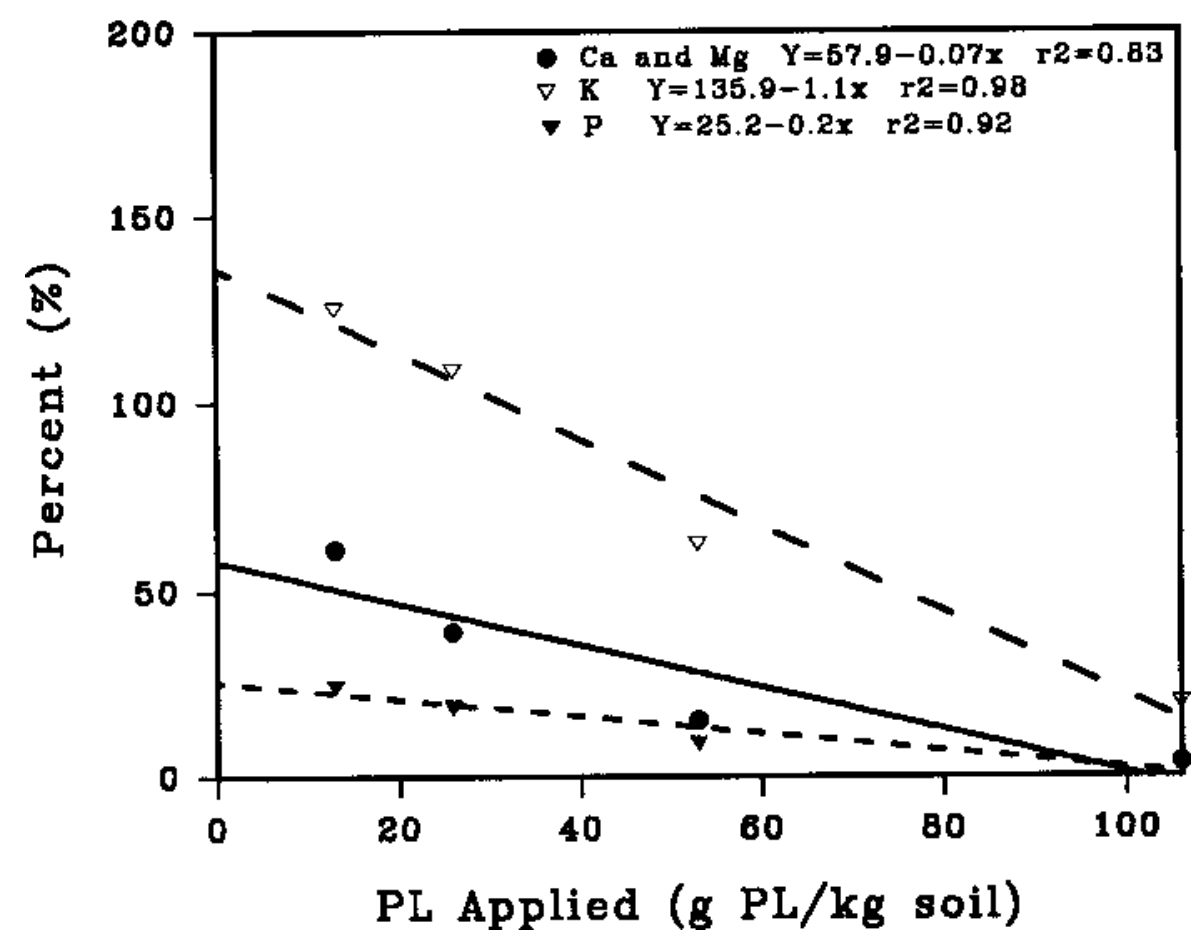

Fig. 5. Mean percent $\mathrm{Ca}, \mathrm{Mg}, \mathrm{K}$, and $\mathrm{P}$ absorbed by one crop of collard plus three crop of cabbage grown in soil initially amended with poultry litter at 13 to $106 \mathrm{~g} \cdot \mathrm{kg}^{-1}$.

soil as affected by broiler litter application rate. PhD Diss., Auburn Univ., Auburn, Ala. (Diss. Abstr. 9402090).

Lu, N., J.H. Edwards, and C.W. Wood. 1991. Extractable macro- and micronutrients from soil incorporated with broiler litter, p. 618-626. In: A.B. Bottcher et al. (eds.). Proc. Conf. Environ. Sound Agr., 16-18 Apr. 1991. Univ. of Florida, Inst. Food \& Agr. Sci., Gainesville.

Mitchell, C.C., J.O. Donald, and J. Martin. 1989.
The value and use of poultry waste as fertilizer. Poultry by-product management-Agronomy. Alabama Coop. Ext. Serv., Auburn Univ., Ala. CP. 5M08, 10:89, ANR-244.

Nelson, D.W. and L.E. Sommer. 1982. Total carbon, organic carbon, and organic matter, p. 561571. In: A.L. Page et al. (eds.). Methods of soil analysis. Part 2-Chemical and microbiological properties. 2nd ed. Agron. Soc. Amer., Soil Sci. Soc. Amer., Madison, Wis.
Payne, V.W.E. and J.O. Donald. 1991. Poultrywaste management and environmental protection manual. Alabama Coop. Ext. Serv., Auburn Univ., Ala. 5M, 1:91, ANR-580.

Petruzzelli, G., L. Lubrano, and G. Guidi. 1989. Uptake by corn and chemical extractability of heavy metals from a four year compost treated soil. Plant Soil 116:23-27.

Rhoades, J.D. 1982a. Cation exchange capacity, p. 149-157. In: A.L. Page et al. (eds.). Methods of soil analysis. Part 2-Chemical and microbiological properties. 2nd ed. Agron. Soc. Amer., Soil Sci. Soc. Amer., Madison, Wis.

Rhoades, J.D. 1982b. Soluble salts, p. 167-179. In: A.L. Page et al. (eds.). Methods of soil analysis. Part 2-Chemical and microbiological properties. 2nd ed. Agron. Soc. Amer., Soil Sci. Soc. Amer., Madison, Wis.

SAS Institute. SAS user's guide. 1988. SAS Inst., Cary, N.C.

Shortall, J.G. and W.C. Liebhardt. 1975. Yield and growth of corn as affected by poultry manure. J. Environ. Qual. 4:186-191.

Siegel, R.S., A.A.R. Hafez, J. Azevedo, and P.R. Stout. 1975. Management procedures for effective fertilization with poultry manure. Compost Sci. 16:5-9.

Thomas, G.W. 1976. Development of environmental guidelines for fertilizer use. Southern Coop. Res. Bul. 211. p. 20.

Weil, R.R., W. Kroontje, and G.D. Jones. 1979. Inorganic nitrogen and soluble salts in a Davidson clay loam used for poultry manure disposal. J. Environ. Qual. 8:86-91.

Wilkinson, S.R. 1979. Plant nutrient and economic value of animal manures. J. Animal Sci. 48(1):121-133.

Wilkinson, S.R., J.A. Stuedemann, D.J. Williams, J.B. Jones, Jr., R.N. Dawson, and W.A. Jackson. 1971. Recycling broiler litter on tall fescue pasture at disposal rates and evidence of beef cow health problems, p. 321-324. In: Livestock waste management and pollution abatement. Proc. Amer. Soc. Agr. Eng. Publ. Proc. 271, St. Joseph, Mich. 